ADVANCES IN TAXATION 


\section{ADVANCES IN TAXATION}

\section{Series Editor: John Hasseldine}

\section{Recent Volumes:}

Volumes 1-3:

Volumes 4 and 5:

Volumes 6-16:

Volumes 17 and 18:

Volumes 19-21:

Volumes 22-27:
Edited by Sally M. Jones

Edited by Jerold J. Stern

Edited by Thomas M. Porcano

Edited by Suzanne Luttman

Edited by Toby Stock

Edited by John Hasseldine 
ADVANCES IN TAXATION VOLUME 28

\title{
ADVANCES IN TAXATION
}

\author{
EDITED BY \\ JOHN HASSELDINE \\ University of New Hampshire, USA
}

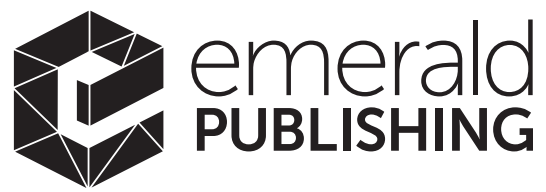

United Kingdom - North America - Japan

India - Malaysia - China 
Emerald Publishing Limited

Howard House, Wagon Lane, Bingley BD16 1WA, UK

First edition 2021

Copyright (C) 2021 Emerald Publishing Limited

\section{Reprints and permissions service}

Contact: permissions@emeraldinsight.com

No part of this book may be reproduced, stored in a retrieval system, transmitted in any form or by any means electronic, mechanical, photocopying, recording or otherwise without either the prior written permission of the publisher or a licence permitting restricted copying issued in the UK by The Copyright Licensing Agency and in the USA by The Copyright Clearance Center. Any opinions expressed in the chapters are those of the authors. Whilst Emerald makes every effort to ensure the quality and accuracy of its content, Emerald makes no representation implied or otherwise, as to the chapters' suitability and application and disclaims any warranties, express or implied, to their use.

\section{British Library Cataloguing in Publication Data}

A catalogue record for this book is available from the British Library

ISBN: 978-1-80043-327-4 (Print)

ISBN: 978-1-80043-326-7 (Online)

ISBN: 978-1-80043-328-1 (Epub)

ISSN: 1058-7497

ISOQAR certified

Management System

awarded to Emerald

for adherence to

Environmental

standard

ISOQAR

ISO 14001:2004. 


\section{CONTENTS}

About the Editor vii

List of Contributors ix

Editorial Board xi

Introduction xiii

The Effects of Level of Government and Use of Funds on Trust in Revenue Agencies

Cass Hausserman, Susan Jurney and Timothy Rupert

Does Understanding Tax Laws Reduce Charitable Giving? A Study of Tax Literacy and Unintended Consequences Amy Hageman and Cass Hausserman

Distributive Justice and the Tax Fairness Partisan Divide

Michael L. Roberts and Theresa L. Roberts

The Use of Tax Accruals to Fool the Market: The Case of PRE before the Tax Cuts and Jobs Act

Zhan Furner, Michaele L. Morrow and Robert C. Ricketts

The Relation between Equity Incentives and Earnings

Management through Permanently Reinvested Foreign Earnings for US Multinational Corporations

Zhan Furner, Keith Walker and Jon Durrant

Why Businesses Locate R\&D in High Tax States: The Role of the States' R\&D Tax Credit Effectiveness

B. Anthony Billings, Buagu N. Musazi, William H. Volz and Deborah K. Jones 
This page intentionally left blank 


\section{ABOUT THE EDITOR}

Since 2011, Dr. John Hasseldine has been a Professor of Accounting and Taxation in the Peter T. Paul College of Business and Economics at the University of New Hampshire. Previously he was a Chair and Head of the Accounting and Finance Department at the University of Nottingham Business School. John, a Kiwi, qualified as a chartered accountant in New Zealand and is a Fellow of the Association of Chartered Certified Accountants (FCCA) based in London.

John has served on three government committees in the UK and was a contributor to the Mirrlees Review of the UK tax system conducted by the Institute of Fiscal Studies. He has been an external expert at the International Monetary Fund, a visiting professor at the University of New South Wales, Sydney, and a keynote speaker at several international tax conferences. He travels widely, speaking at national and global conferences, including one on VAT organized by the OECD, World Bank, and IMF, and a conference on dealing with the national tax gap held at the US Library of Congress in Washington DC. He is a co-author of Comparative Taxation: Why Tax Systems Differ (Fiscal Publications, 2017), and an International Fellow at the University of Exeter Tax Administration Research Centre.

John received his $\mathrm{PhD}$ in Accounting in 1997 from the Kelley School of Business at Indiana University-Bloomington, and his Master of Commerce in Accounting and Bachelor of Commerce from the University of Canterbury, Christchurch, New Zealand. 
This page intentionally left blank 


\section{LIST OF CONTRIBUTORS}

B. Anthony Billings

Jon Durrant

Zhan Furner

Amy Hageman

Cass Hausserman

Deborah K. Jones

Susan Jurney

Jeremy Lee

Michaele L. Morrow

Buagu N. Musazi

Alexey Nikitkov

Robert C. Ricketts

Michael L. Roberts

Theresa L. Roberts

Timothy Rupert

William H. Volz

Keith Walker
Wayne State University, USA

California State University, Fullerton, USA

East Carolina University, USA

Kansas State University, USA

Portland State University, USA

Wayne State University, USA

Oklahoma City University, USA

University of Waterloo, Canada

Merrimack College, USA

Morgan State University, USA

Brock University, Canada

Texas Tech University, USA

University of Colorado Denver, USA

Northeastern University, USA

Wayne State University, USA

University of Toledo, USA 
This page intentionally left blank 


\section{EDITORIAL BOARD}

John Hasseldine, Editor

University of New Hampshire, USA

Kenneth Anderson

University of Tennessee, USA

Bryan Cloyd

Lehigh University,

USA

Anthony Curatola

Drexel University, USA

Chris Evans

University of New South Wales Sydney,

Australia

Pete Frischmann

Oregon State University, USA

Norman Gemmell

Victoria University of Wellington,

New Zealand

Kevin Holland

Cardiff University, UK

Khondkar Karim

University of Massachusetts Lowell,

USA

Beth Kern

Indiana University-South Bend, USA

Erich Kirchler

University of Vienna,

Austria

Stephen Liedtka

Villanova University, USA

Alan Macnaughton

University of Waterloo, Canada
Amin Mawani

York University, Canada

Janet Meade

University of Houston, USA

Emer Mulligan

National University of Ireland Galway,

Ireland

Lynne Oats

University of Exeter, UK

Grant Richardson

Macquarie University, Australia

Robert Ricketts

Texas Tech University, USA

Michael Roberts

University of Colorado-Denver, USA

Timothy Rupert

Northeastern University, USA

Adrian Sawyer

University of Canterbury, New Zealand

Toby Stock

Ohio University, USA

Michael Walpole

University of New South Wales Sydney, Australia

Marty Wartick

University of Northern Iowa, USA

Christoph Watrin

University of Muenster, Germany

Le (Emily) Xu

University of New Hampshire, USA 
This page intentionally left blank 


\section{INTRODUCTION}

In Volume 28, there are seven chapters. In the lead chapter, Cass Hausserman, Susan Jurney, and Tim Rupert experimentally investigate how the level of government (either federal or state) and whether funding that is being allocated to enforcement or service efforts in a revenue agency affect trust in the revenue agency. They find that the two independent variables interact, such that trust in the state agency is not affected by whether the proposed funding would be allocated to service or enforcement efforts. But, at the federal level (the Internal Revenue Service), trust in the agency is significantly higher when the proposed funding is to hire additional service employees as opposed to hiring additional enforcement employees. Additionally, they find that the level of government moderates the mediating effect of trust in the agency on the relation between the use of funds and support for the funding.

Next, Hageman and Hausserman examine taxpayers' knowledge of tax incentives for charitable giving, and also the consequences of this knowledge on charitable giving decisions. Their first study establishes a baseline understanding of how making a charitable contribution affects taxpayers. In a second study, they experimentally manipulate the knowledge of taxpayers by providing an educational intervention; while measuring if, and how much, is donated in a hypothetical scenario. The first study indicates fewer than half of participants understand the basic principles of how charitable donations affect tax liability. Their second study reveals that a short educational video was extremely effective at improving taxpayers' understanding and helping them accurately estimate the tax benefit associated with charitable giving. Although they show that participants who received this educational intervention and accurately estimated the tax benefits in turn decreased their charitable giving suggesting taxpayers may be overestimating the benefit they receive from charitable giving, resulting in giving more than intended.

In the third chapter, Roberts and Roberts examine how public attitudes and judgments about tax fairness reflect distributive justice rules about proportionality/contributions, needs, and equality; fairness issues that influence voluntary tax compliance. The authors show that, viewed in combination, two distributive justice rules explain the tax fairness judgments of 89 percent of their sample and indicate surprising general agreement about what constitutes a fair share of income taxes that should be paid by US citizens from the 5 th percentile to the 95th percentile of the income distribution. Roberts and Roberts conclude the joint application of the Needs rule of distributive justice theory and the 
Contributions rule of equity theory indicates how seemingly competing, partisan distributive justice concerns can inform our understanding of social attitudes about tax fairness across income classes.

The next two chapters are related contributions. In the fourth chapter, Furner, Morrow, and Ricketts analyze how the designation of foreign earnings as "permanently reinvested" outside the US (PRE) is related to subsequent firm growth and market returns. They note that prior research suggests that firms that hold excess cash in foreign markets to avoid the US corporate income tax experience lower growth, since such "trapped" cash is inefficiently invested. However, foreign earnings can be inefficiently invested in forms other than cash. The authors hypothesize and find that as the ratio of PRE to total assets increases, firms' growth rates decline. Their results suggest that trapped earnings, and not just trapped cash, are associated with lower growth. Because PRE has also been associated with earnings management in the literature, they also analyze the association between the use of PRE to meet or beat earnings targets and subsequent growth, observing a significant and persistent negative association.

Next, Furner, Walker, and Durrant examine whether the equity incentives of management are associated with an increased use of PRE. The authors predict and find strong evidence that the changes in PRE are positively associated with the portion of top managers' compensation that is tied to stock performance. In addition, they find this relationship to be strongest for firms that met or beat forecasts, but only with the use of PRE to inflate income, suggesting that equity compensation incentives managers to opportunistically use PRE, especially to meet analyst forecasts.

Billings, Musazi, Volz, and Jones study the effectiveness of states' research and development ( $R \& D$, used to represent creditable research expenses) tax credits. Prior studies consider the influence of state R\&D tax credits by applying the statutory income tax and $\mathrm{R} \& \mathrm{D}$ credit tax rates. The authors reexamine the effect of a state's entire tax burden instead of the statutory tax rates in moderating the effectiveness of a state's R\&D tax credit incentives. After controlling for several nontax factors in a regression analysis during the 2010-2013 period in 50 states, they find that statewide private-sector $R \& D$ spending is a positive function of the R\&D tax credit and this effect increases with the overall level of the state tax burden. They attribute this finding to the fact that high tax burdens increase the present value of the $\mathrm{R} \& \mathrm{D}$ tax credits

Lastly, Lee and Nikitkov note that the rapid rise of electronic commerce has exacerbated consumer evasion as cross-border selling over the Internet has enabled foreign businesses to sell and avoid collection and remittance of tax on their sales. The authors search for the solution to this problem through the analysis of three tax collection models: Vendor, Financial institution, and Internet Service Provider (ISP). In addition, they examine administrative tools that enable more effective collection as well as inducements for taxpayers or collection agents to carry out their responsibility. Lee and Nikitkov conclude that 
the ISP collection model is not feasible at this time. On the other hand, they find that the vendor model, when supplemented with appropriate administrative tools and inducements, as well as the financial institution model, both represent viable options for policymakers to consider.

John Hasseldine

Editor, Advances in Taxation 